UDK: 27(528.9):355.4

DOI: $10.5937 / J R S 1901005 P$

Received: 28 March 2019 / Accepted: 17 May 2019

\title{
Introduction to the Special Issue on Mapping International Security
}

\author{
MILOŠ POPOVIĆ* \\ Arizona State University, US
}

For centuries, cartographers have created maps to depict conflict, peace, and security around the globe. Used as a means of territorial production ${ }^{1}$ or construction of power structures, ${ }^{2}$ cartography has long been limited to elites. Thanks to the development of open-source geospatial services such as OpenStreetMap (OSM) or Google Earth, cartography has left the door wide open for enthusiasts and scholars. Recent findings show that between 2007 and 2015 the number of graduate degrees in cartography almost doubledand that with the light-speed development in satellite technology and GIS software, the demand for cartographers will rise in the next decade. ${ }^{3}$ Cartography has become a new code in data visualization from the New York Times to Uber and Lyft to various conflict observers.

Cartography is also experiencing a renaissance in conflict studies: several databases such as The Armed Conflict Location \& Event Data Project (ACLED), Global Terrorism Database (GTD) or UCDP's Georeferenced Event Dataset offer fine-grained geospatial information on human rights violations, insurgency, political violence and terrorism, and protests. This impressive collection of spatial knowledge allows scholars to analyze new evidence, come up with new research questions or re-evaluate existing theories. For example, Guo et al. (2017) apply GIS and network science to information from these datasets to show that network of cities rather than intricate ethnoreligious, socio-economic or political relations is closely related to violence.

Riding on this new wave of cartography, this special issue of Journal of Regional Security introduces several important contributions to the area of peace and security. Our contributors use cartography to shed light on several relevant questions: How does the violent past affect the features of statehood? To what extent is there a variation in violence on the sub-state level across the world? What is the role of non-state actors in producing

\footnotetext{
1 Elden 2010.

2 Harley 1968.

3 Wired. 2017. "Mapping the future of cartography stages a comeback." Last accessed 17 May 2019. https://www.wired.com/story/mapping-the-future-cartography-stages-a-comeback/

*milos.agathon@gmail.com
} 
(in)security? How do these actors challenge the state monopoly on the use of force? Can the state and non-state actors cooperate in defining security threats?

One of the key findings in conflict studies is that wars destroy the economic, political and social fabric of the society, leaving deep scars on the identity of its elites and population. Some countries are born after wars of independence, others had to defend their independence against invaders, and certain countries pursued aggressive policies toward their neighbors. Using one of the most important symbols of modern statehood, Bobić and Kantorowicz explore whether a militaristic past sheds light on the tone of national anthems worldwide. Using the sentiment analysis of national anthems, they find that the negative sentiment in anthems tends to overlap with the initiation of militarized interstate disputes (MID). This finding may be related to a bloody past if a nation was forged in war, underwent foreign invasion, or conquered other countries.

While numerous studies in conflict resolution analyze either cross- or intra-country variation in violence, there are a few collaborative projects such as the Uppsala Conflict Database Program (UCDP) or the Armed Conflict Location \& Event Data Project (ACLED) that offer fine-grained data on the cross-country subnational level. Stueber and Geugjes followed the latter in that they present the intensity of civil conflict across the subnational units in 2017. They utilize the Heidelberg Institute for International Conflict's (HIIK) Conflict Barometer to map sub-state conflicts between the government and nonstate actors that can range from protests to war. This map shows that while violence clusters in space, there is a considerable variation in conflict intensity within countries. For instance, some turbulent countries like Afghanistan, Sudan and Yemen experienced the whole spectrum of violence from sporadic clashes to the limited conflict to full-blown war. Mapping subnational variation allows practitioners to monitor ongoing crises in a more meticulous way.

States are not the sole actors in world politics as numerous non-state actors, from ethnic groups and militant outfits to private companies can also produce (in)security. Hammerschmidt and Meyer map the eruption of violence on the eve of the 2005 Parliamentary Election in Afghanistan to analyze the relationship between insurgent violence and elections. They show that the violence was concentrated in the Talibancontrolled areas and intensified as the election day was approaching. Similarly, Schouten and Jaillon use data from a few hundred interviews of members from various ethnic groups in the Central African Republic to map roadblocks in the country. Roadblocks are more than a physical obstacle: they demonstrate the spatial fragmentation of state control over trade, a key source for all parties in the civil war. The map highlights three key trade routes where state territorial control yields to non-state actors and vice versa.

The monopoly on the use of force is what makes a modern state. Some of our contributions show how non-state actors challenge this canonical feature. Pontarollo and Ricciuti portray the limits of Italy's monopoly on the use of force in Sicily with a map of mafia killings in Palermo over the last century. Using a kernel density estimation, the authors show that a 
higher intensity of massacres has been concentrated in downtown Palermo. The ability of the mafia to conduct numerous murders of state officials in the heart of Palermo offers a stark reminder that the government is not the only player in town. Similarly, governments have increasingly framed terrorism as one of the most significant non-state challenges to their sovereignty particularly following the 9/11 attacks. Nemeth and Mauslein show that the proliferation of terrorism rhetoric does not coincide with the global risk of terrorism. In fact, Nemeth and Mauslein's geospatial predictive model demonstrates that the risk of domestic terrorism is generally low even in those areas that underwent bloody conflicts. This finding runs against the popular belief that terrorism is the most prevalent form of violence in the contemporary world. It also suggests that security is an intricate web of various narratives where the most dominant does not necessarily reflect actual threats.

While states face security threats stemming from non-state actors, unprecedented technological development has simultaneously brought some governments and private companies into partnership. Olbrich's map shows how one such partnership between the US government and DigitalGlobe, a leader in commercial satellite imagery, plays out in the field of monitoring hotspots in North Korea. Even though DigitalGlobe is a private company, Olbrich's map shows that US national security interests heavily influence its imagery of North Korea because high-intensity points are centered around the industry and military objects. This map suggests that private satellite imagery companies are a powerful social actor that filter collected data to advance specific security issues in the social space. In doing so, these actors reshape not just state policy but the very meaning of security.

Maps are a powerful instrument for transforming our perception of the world. As contributions in this special issue show, maps shed new light on such contentious issues such as sovereignty, terrorism, and civil war. Cartography helps us challenge existing theories, come up with new arguments and chart out directions for future research. However, cartography's riches are an untapped potential both in classroom and research despite the proliferation of digitized maps and open-source services. It goes without saying that using maps in the classroom allows students to visualize events and trends better; adds a spatial dimension to their thinking; and brings distant places closer to them. Investing more into partnerships between the political science department, and GIS departments and libraries would greatly contribute to the cultivation of future generations of international relations scholars.

Mapping security also offers avenues for future research, as our contributors' show. Given the latest turn toward the micro-level analysis in conflict studies, future research would greatly benefit from mining data from Open Street Maps to explore the interactions between geography and violence. Another fertile area for researchers is exploring how geography aids or impedes terrorism. Finally, there is considerable unused potential 
in understanding how the geography of violence during the war (for example, aerial bombing, ethnic cleansing, genocide, massacres) affects post-war politics.

\section{References}

Elden, Stuart. 2010. "Land, terrain, territory." Progress in Human Geography 34(6): 799-817.

Guo, W., Lu, X., Donate, G.M. and Johnson, S. 2016. The spatial ecology of war andpeace.arXiv preprint arXiv:1604.01693.

Harley, J. Brian, 1968. “The Evaluation of Early Maps: Towards a Methodology” Imago Mundi 22: 62-74. 